UDC 347.121.2

DOI https://doi.org/10.32849/2663-5313/2021.11.04

\title{
Taras Sofiuk,
}

PhD in Law, Associate Professor at the Department of International, Civil and Commercial Law, Kyiv National University of Trade and Economics, 19, Kyoto street, Kyiv, Ukraine, postal code 02156, t.sofiuk@gmail.com

ORCID: orcid.org/0000-0002-8949-3336

Scopus Author ID: 57217833407

\section{Larysa Neskorodzhena,}

PhD in Law, Associate Professor at the Department of International, Civil and Commercial Law, Kyiv National University of Trade and Economics, 19, Kyoto street, Kyiv, Ukraine, postal code 02156, l.neskorodzhena@knute.edu.ua

ORCID: orcid.org/0000-0002-1484-3557

\section{Yuliia Kabenok,}

PhD in Law, Associate Professor at the Department of International, Civil and Commercial Law, Kyiv National University of Trade and Economics, 19, Kyoto street, Kyiv, Ukraine, postal code 02156, y.kabenok@knute.edu.ua

ORCID: orcid.org/0000-0001-9342-3835

Scopus Author ID: 57212105878

Sofiiuk, Taras, Neskorodzhena, Larysa, Kabenok, Yuliia (2021). The right of the natural person to individuality. Entrepreneurship, Economy and Law, 11, 27-41, doi https://doi.org/10.32849/2663-5 $313 / 2021.11 .04$

\section{THE RIGHT OF THE NATURAL PERSON TO INDIVIDUALITY}

Abstract. The purpose of the research is to substantiate the need for statutory consolidation of the human right to intellectual freedom as an integral component of the right of a natural person to individuality.

Research methods. The contribution was developed by relying on the following methods of scientific cognition: analysis, synthesis, logical semantics, the method of studying information sources, as well as formal-logical, dialectical, retrospective, prognostic methods.

Results. The article studied theoretical approaches to the analysis of the history of the human right to individuality and individual freedom available in scientific and philosophical thoughts. The authors paid attention to the understanding of the concept of individual freedom and its significance in the modern world. The research showed that the maintenance of a good condition of human affairs and thus harmony of civilized life in the modern era primarily involves establishing and protecting human individuality from mental and emotional captivity and hence establishing and protecting the scope of individual consciousness independent of the control of the majority, even in the form of a public opinion. It was proved that "the interest of the majority" per se without its civilized "fertilization" with the idea of the absolute value of human personality is at least not identical, rather opposite to the "harmony of civilized life". The authors demonstrate that an unjustified "invasion" of the will of the majority in the realm of individual freedom and the actual suppression of the human right to individuality, which become possible due to the lack of effective legal and social safeguards against the public will, are often the consequences of the collision between individual and group rights in modern societies. The significance of intellectual freedoms for mass societies was studied. Particularities of intellectual life in the democratic epoch were clarified. The authors drew attention to modern threats to freedom of thought. It was highlighted the need to develop and protect the intellectual freedom of an individual.

Conclusions. According to the results of the study, the following conclusions about the harmonization of human individuality with social solidarity are substantiated: 1) it is proposed to admit that incorrect, exaggerated understanding and application of a noble idea of human solidarity may lead to the crisis of human individuality in modern civilization; 2) this crisis may be manifested, in particular, in impediments affecting the desire to have and support one's cultural identity and in restraining the very desire; 3 ) it is proposed to admit that intellectual freedoms and intellectual life in modern mass societies are gaining specific attention and, at the same time, are in danger; 4) it is proposed to add para. 3 to art. 300 
of the Civil Code of Ukraine and present it in the version as follows: "A natural person shall have the right to intellectual freedom - the right to the development of conscious attitude to oneself and the world, the implementation of personal creative initiative, intellectual development, incl. through discussion. A natural person shall be free from judgments, concepts, feelings, and prejudices of others' opinion, as long as it does not harm others". The authors hold that human individuality is incomplete in today's context without promoting intellectual freedom.

Key words: individuality, individual freedom, public opinion, "tyranny of the majority”, culture, mass society, intellectual freedom.

\section{Introduction}

Every person shall have the right to free development of his personality, provided that the rights and freedoms of other persons are not thus violated (art. 23 of the Constitution of Ukraine). The "individuality" concept as an object of the relevant right is conveyed by the legislator as the intangible personal benefit of an individual, which includes a set of his mental properties, characteristics, life and professional experience, that distinguishes him from other individuals. Individuality consists of many particularities of a natural person related to his national, cultural, religious, linguistic, and other kinds of identity (Dzera et al., 2019, p. 442). At the same time, originality is the personal identity, the realization of own belonging to a particular social group or community. It is usually expressed in the subject's appearance. Individuality, in turn, is manifested in language, behavior, religious affiliation, worldview, attitude to others, communication style, character traits, temperament, habits, priority interests, cognitive processes, abilities, individual activity style, etc. Individuality is exclusively personal, intangible, social benefit. Moreover, external anatomic features are not considered by the concept (Spasybo-Fatieieva, 2021, p. 712).

The right to individuality implies that a natural entity: a) has own identity, i. e., he is recognized as a holder of the intangible personal benefit. The right to preserve one's national, cultural, religious, linguistic originality, which is guaranteed by art. 2 of article 300 of the Civil Code of Ukraine and art. 11 of the Constitution of Ukraine, is close in its meaning; b) uses personal identity, i. e., to choose any possible form and way to display his individuality unless they are prohibited by the law and contradict the moral principles of society (para. 2 of article 300 of the Civil Code of Ukraine); c) creates and changes his individuality; d) requires protection in case of any violation of the right to individuality. The protection of the right is carried out on the grounds of and in the manner prescribed in section 3 and articles 275-280, 1166-1168 of the Civil Code of Ukraine (Dzera et al., 2019, p. 443).

The European Court of Human Rights holds it inadmissible to ignore the aspirations of a person (a community) to have and maintain his cultural identity, even if the majority of society no longer keeps up traditions due to the influence of progress and personal choice; ethnic (national) identity is an essential aspect of a person's private life (SpasyboFatieieva, 2021, p. 713). The person can join national groups, adhere to certain traditions, wear national, cultural, and religious symbols, develop culture, communicate in a particular language, create works, etc. (Spasybo-Fatieieva, 2021, p. 714)

The following authors studied the regulation of intangible personal rights related to the human right to individuality: O.S. Hyliaka, Yu.O. Zaika, A.O. Kodynets, O.V. Kokhanovska, N.S. Kuznietsova, O.O. Kulinich, N.V. Kushakova-Kostytska, R.A. Maidanyk, O.V. Petryshyn, O.O. Posykaliuk, S.O. Slipchenko, R.O. Stefanchuk, Ye.O. Kharytonov, O.I. Kharytonova and other (Kharytonov, Kharytonova, 2018; Kodynets, 2016; Kokhanovska, 2006; Kokhanovska, 2020; Kulinich, 2016; Kushakova-Kostytska, 2018; Kuznietsova et al., 2013; Petryshyn, Hyliaka, 2021; Posykaliuk, 2012; Slipchenko, 2013; Stefanchuk, 2007; Stefanchuk, 2010; Zaika et al., 2021).

However, the domestic science of civil law has not yet paid proper attention to the consistency of the growing social solidarity with the human right to individuality. This fact triggers the need to settle a complex of important scientific and practical tasks:

- to examine approaches to the understanding of individual freedom and its significance;

- to study consequences of a collision between individual and group rights;

- to elucidate the significance of intellectual freedoms in mass societies.

The purpose of the article is to substantiate the need for statutory consolidation of the human right to intellectual freedom as an integral component of the right of a natural person to individuality.

Modern scientists have touched upon some aspects of the issue under consideration. In particular, there are studies devoted to honor and dignity following laws of the countries of Continental Europe (Zaika, 2017). 
However, the realm of the human right to individuality contains issues which must be thoroughly analyzed. The article covers the issues as follows:

- study of theoretical approaches to the analysis of the history of the human right to individuality and individual freedom available in scientific and philosophical thoughts;

- clarification of the correctness of the statement about groundless identification of the concepts of "harmony of civilized life" and "the interest of the majority";

- identification of possible modern threats to the human right to individuality;

- study of particularities of intellectual life in the democratic epoch.

Using the method of scientific analysis, the authors sought to divide the research object into components and elucidate its features and connections with other elements in the system by relying on its components. Synthesis was applied to unite previously separated parts into a coherent whole. Logical semantics was used to elicit the significance of the framework of concepts and categories involved in the research and its interpretation. According to the method of studying information sources, the authors analyzed scientific contributions devoted to the right of a natural person to individuality in domestic and international legal science. The Aristotelian method facilitated the harmonization of major components of the study of the right of a natural person to individuality with the laws of formal logic. The dialectical method facilitated identifying the evolution of legal theory and practice in exercising the right of a natural person to individuality. The retrospective method was applied to study the historical development of the right of a natural person to individuality and its becoming as a legal category. The prognostic approach helped develop the recommendations for improving domestic civil laws to ensure their compliance with the need to reconcile growing social solidarity with the human right to individuality.

\section{The history of individual freedom}

There are inviolable and immutable laws of social life, which determine the preservation and evolution of public life: they are eternal per se and in their inner meaning; however, these empirical laws may be violated and are often violated that result in the fall or, at best, paralysis, weakening, and disease of society. It is precisely the laws that have always been meant in the doctrine of "natural law". Pursuant to the laws, man has a firm benchmark of what must be true, something towards which he must direct and adapt his aspirations. Man is a free being; he is free to choose his life path as he sees fit. He may make mistakes, and then he perishes; he may obey the requirements of truth, laws established not by his will but by the source of the highest truth, and then he asserts and strengthens his life (Frank, 1992, p. 34). All human rights eventually arise from the only "inherent right": the right to demand to be given the opportunity to fulfill his duty (Frank, 1992, p. 109). The object "towards which every human being must ceaselessly direct his efforts is the individuality of power and development"; for this there are two requisites, "freedom, and variety of situations"; from the union of these arise "individual vigour and manifold diversity", which combine themselves in "originality" (Von Humboldt, as cited in (Mill, 2001, p. 54)). Additional individual rights arising from the principle of freedom and personal identity are indirectly established in the obligation to protect individual freedom as a legitimate, i. e., obligatory, beginning of human life (Frank, 1992, p. 109).

However, what does it mean to say that a right is fundamental, and according to what standards of importance or urgency is it so judged? (Weston, 2021).

To answer the above question, the authors refer to the history of the human right to individual freedom.

The ancient world could differentiate between "natural", internally authoritative, divine in its origin law and positive law, originating from state power or a conditional agreement between people, but the difference between law and morality in our sense of these concepts was unknown in that period (Frank, 1992, p. 82). Morality was undistinguished from religion and politics from morals; and in religion, morality, and politics there was only one legislator and one authority (DalbergActon, 1949, p. 45). "In this period of history, it is necessary to be endowed with an unstoppable genius to not be assimilated" (Hennequin, as cited in (Guyau, 1900, p. 70)). The influence of the social environment for most great geniuses ceased to be predetermining in largely civilized societies, like Athens in the times of the Sophists, imperial Rome (Guyau, 1900, p. 71). Freedom arose in the Middle Ages (Fedotov, 2004, p. 103). Freedom under discussion is social freedom, which is based on two truths. The former is the absolute value of an individual ("soul"), which cannot be sacrificed for any collective the people, the state, or the Church. The latter is the freedom to choose the path - between verity and falsity, good and evil (Fedotov, 2004, p. 110).

In the modern world, the greater size of political communities, and, above all, the separation between spiritual and temporal 
authority (which placed the direction of men's consciences in other hands than those which controlled their worldly affairs), prevented an interference by law in the details of private life (Mill, 2001, pp. 16-17). As Lord Acton put it, "with the decline of coercion the claim of Conscience rose, and the ground abandoned by the inquisitor was gained by the individual" (Dalberg-Acton, 1921, p. 31). As an individual becomes a part of a social whole, more modified and more widespread, the better organization of which will require few moral sacrifices on the part of citizens, the latter will be able to preserve their personal qualities more easily without being forced to acquire extreme strength to withstand extreme social pressures. Hence, it follows the progression of individuality and personal freedom, which has lasted since ancient times (Guyau, 1900, p. 70).

In this context, the following question may arise: what are individuality and personal freedom?

Evil Ramovich suggested "understanding individuality in the sense of a subjective mouthpiece of the combination of internal characteristics and those internal conditions under which a human being transforms into a consciously and peculiarly responsive person" (Ramovich, 1903, p. 10). J.S. Mill brilliantly analyzed the phenomenon of personal liberty: "the region of human liberty comprises, first, the inward domain of consciousness; demanding liberty of conscience; liberty of thought and feeling; absolute freedom of opinion and sentiment. The liberty of expressing and publishing opinions belongs to that part of the conduct of an individual which concerns other people; but, being almost of as much importance as the liberty of thought itself, is practically inseparable from it. Secondly, the principle requires liberty of tastes and pursuits; of framing the plan of our life to suit our own character; of doing as we like, subject to such consequences as may follow: without impediment from our fellow creatures, so long as what we do does not harm them, even though they should think our conduct foolish, perverse, or wrong. Thirdly, from this liberty of each individual, follows the liberty, within the same limits, of combination among individuals; freedom to unite, for any purpose not involving harm to others: the persons combining being supposed to be of full age, and not forced or deceived" (Mill, 2001, pp. 15-16).

The conscious shift of the system of rights towards individualistic elements took place in the $18^{\text {th }}$ century when the famous doctrine of natural law finally matured. It stated that everyone has the right to enjoy common goods which had previously belonged to the elite (Ramovich, 1903, pp. 168-169). Equality is in generosity, not in a lack of legal rights (Fedotov, 2004, p. 105). A person was granted the rights in the light of the very fact of his birth (Ramovich, 1903, p. 169). The optimistic vision became a common prerequisite: a free struggle of the elements within an individual and society led to harmony or promotion of creative energies. During two or three generations, a life lived up to these hopes (Fedotov, 2004, p. 112).

At the beginning of the 18th century, "personal liberty" turned into the intelligentsia's slogan; it was supposed to fill the emptiness of the concept of the highest good and change the old ideals. However, having changed these ideals, liberty could not replace them. Individual liberty cannot be a goal guiding a person's life. It is only a means, although necessary, but for the best achievement of other goals. Liberty itself does not harmonize the mutual relations of group members, does not provide an individual with any definite idea of good and evil, does not do a painting of the desired future in view of which we could choose the right path for applying our creative instincts. The freedom of spirit nourishes our creativity just till one must achieve it; however, having achieved freedom, people subsequently miss a guiding principle. Decadence began in a long while. The truths discovered by science and wealth accumulated by the industry had no longer delightful. Human contributions seemed to be drowning in the abyss of aimlessness. In terms of short-term personal existence, progress products were not worth the efforts invested. It was not of public interest to work without bearing in mind that it contributes to the happiness and improvement of future generations. The lack of an ideal discouraged people from struggling and working and made them feel redundant. It caused despondency and skepticism, prostration and poor creativity, glum views on society and social progress (Ramovich, 1903, pp. 312-313).

The 19th century lost the power and need to createand construct. Man lost himself in the mass of objects. Even such a natural phenomenon as the struggle for existence, following the spirit of the times, could be considered the norm for human history. Man lost his faith in the power of personality (Barth, 1902, p. 345).

In the last quarter of the 19th century European thought became a prey to selfdoubt and the fear of decadence (Barzun, 2021). The basis of Decadence - bitter regret for the loss of a world of moral and political absolutes, and middle-class fears of supersession in a society where the power of the masses (as workers, voters, purchasers, and consumers) 
is slowly but inexorably on the increase (Robinson, Birkett, 2021). The impulse of Realism had generated the middlebrow, while the evolution of industrial democracy had generated the mass man (Barzun, 2021) The increasing influence of public opinion on the conduct of affairs was yet another new factor which had to be taken into account (Montgomery, 1968, p. 411). As Stendhal put it earlier "the tyranny of public opinion (and what public opinion!) is as stupid in the little towns of France as in the United States of America" (Stendhal, 1916, p. 4). It seemed as if all noble thought and true emotion had been suffocated (Barzun, 2021).

Society, which had lost its shrines, inevitably lost its inner peace (Trubetskoy, 1919, p. 14). The fierce struggle for existence did not contribute to the development of personality but, on the contrary, broke it (Barth, 1902, pp. 345-346). Freedom from sin and personal responsibility, the loss of the hateful and sick "the self" attracts the European soul (Fedotov, 2004, p. 159).

TheWesternworldlostitssenseofidentitywas still full of strength (Fedotov, 2004,p. 160). From under the despair and decadence, the scattered retreats and the violent nihilism, human strength was trying to reshape the civilization that all found so unsatisfactory (Barzun, 2021). A new chapter is a renewal through violence (Fedotov, 2004, p. 161). In opposition to the mainstreams, the revolt of the minority awakened. The doctrines of the superhuman and master morality, down to the misconceptions of theoretical anarchism, became understandable only against the backdrop of the era seeking to proclaim the peremptory right of the majority (Jellinek, 1906, p. 47).

What has been called the politics of cultural despair fastened on a great many saviours as the new hope - monarchy, "integral nationalism", a new aristocracy, technocracy, the proletariat, a corporate state, or the mystic unity of "blood" and "race". In all these creeds the thirst for the ideal is evident; together they formed a new utopianism, of which the later fruits are quite other than those predicted: Soviet and Chinese communism, Italian fascism, German National Socialism. As the 19th century passed into the 20th, all the violent rival energies seeking an ideal found an unexpected outlet. The occasion for battle was the Dreyfus affair. Its cultural suggestiveness is apparent: on one side, the ideal of justice and the regard for the individual as an end in himself; on the other, the social or collective ideal (Barzun, 2021).

B.H. Weston argued that "individualistcollectivist debate was especially evident during the period of the Cold War" (Weston, 2021).
In 1991 the Leninist experiment had failed as definitively as that of the fascists a generation earlier (Brogan, 2021). The notion of liberty, a shield that safeguards the individual - alone and in association with others - against the abuse of political authority is the core value. Western liberal conception of human rights is sometimes romanticized as a triumph of the individualism over glorification of the state (Weston, 2021). Yet Western democracy faces other problems that may prove too big for it to solve (Brogan, 2021).

The study of theoretical approaches to the analysis of the history of the human right to individuality and individual freedom available in scientific and philosophical doctrines helps us to understand the concept of individual freedom and its significance better. It is worth supporting the statements found in literature about the nature of personal freedom and the consequences of misuse of this good.

As one author put it "the lack of a new universal ideal in society - individual freedom was mistaken for that - was naturally accompanied $<\ldots>$ by the confusion of minds" (Ramovich, 1903, p. 325). The possession of a clear and definite ideal of society seems dangerous to its possessors (Creighton, 1949 , p. 371). Freedom is the primary obligation of an individual as a general and supreme condition for performing all his other obligations; thus, being an obligation, it becomes the right because the right is an absolute claim to the performance of the obligation (Frank, 1992, p. 115).

Lord Acton put it: "By liberty I mean the assurance that every man shall be protected in doing what he believes his duty against the influence of authority and majorities, custom and opinion" (Dalberg-Acton, 1949, p. 32).

Personal liberty has a functional value, not self-sufficient (Frank, 1992, p. 142). Man is not the highest being in the world. He is not the endpoint the world gravitates to, but the middle stage of global recovery. Therefore, it turns out that it is impossible to stop at the middle stage (Trubetskoy, 1919, p. 21).

Freedom, after all, is not merely emancipation, meaning the liberation or relaxation or absence of rules imposed on people by society, church, or state, by religion or government, by the tyranny of a ruler, by a minority, or by a majority. Freedom means the capacity to know something about oneself, and the consequent practice or at least the desire to live according to limits imposed on oneself rather than by external powers. This appetite for freedom is not extinct, not even in today's world; but the present "cultural" atmosphere provides something very different, indeed 
contrary to its proper nourishment (Lukacs, 2005, p. 222)

Thus, despite the eventually declared triumph of individualism as a defining feature of our time, the issue of a proper understanding of personal freedom is still relevant. As the history of mankind shows, a misunderstanding of the phenomenon by masses threatens civilization with serious social diseases and catastrophes. The authors propose to support the standpoint expressed in literature, which states that the personal freedom of man is primarily essential as a fundamental means assisting him to achieve other goals, among which the development of human individuality is almost the most important. The very advantage of individualism over the glorification of the state may not be enough to allow human individuality to progress freely.

What threats to the proper nourishment of individual freedom does the current "cultural" atmosphere pose? The authors refer to opinions on the so-called "Tyranny of the Majority" expressed in literature to answer this question.

3. "The Tyranny of the Majority"

Lord Salisbury put it: "Free institutions, carried beyond the point which the culture of the nation justifies, cease to produce freedom. There is the freedom that makes every man free; and there is the freedom, so-called, which makes every man the slave of the majority" (as cited in (Lukacs, 2005, p. 225)). Prince E.N. Trubetskoy argued: "There are two <..> concepts of democracy $<\ldots>$ one establishes democracy on the rule of force. Such an understanding of democracy is incompatible with freedom. If people's power is the supreme source of all norms prevailing in co-existence, then $<\ldots>$ life, freedom, and property of man entirely depend on the whim of the majority $<\ldots>$ democracy degenerates into massive despotism. Another concept $<\ldots>$ takes the recognition of the absolute value of the human being as the basis of democracy... it excludes the possibility of bringing an individual down to the level of means and guarantees his freedom, regardless of whether he is a representative of the majority or minority" (Trubetskoy, 1918, pp. 9-10).

The fear of "majority tyranny" was a common theme in the 17th century and later, even among those who were sympathetic to democracy. Given the opportunity, it was argued, a majority would surely trample on the fundamental rights of minorities (Dahl, 2021).

The authors try to find out whether something like that can happen in modern society, and if so, under what circumstances it can become a reality. Thus, the authors refer to some opinions on the harmonization of social solidarity with the personal freedom of man.

As one writer put it, "without being able to degenerate into arbitrariness that would disrupt the harmony of civilized life (i. e., the interest of the majority), the freedom of each individual is automatically limited by the interaction of freedoms of all others and therefore settled not without struggle and hesitation - by an equal distribution of rights and responsibilities" (Ramovich, 1903, p. 256).

Are "harmony of civilized life" and "interest of the majority" always identical concepts? Is such identification legitimate in general? From our point of view, the above concept of social harmony is controversial enough. The following question is also important in this context:

What happens when individual and group rights collide? (Weston, 2021).

Let's look for ways to solve this problem. Let's consider the circumstances under which, when individual and group rights collide, literature prefers the latter. It seems that the below statements cannot be refuted.

The very essence of society implies that every society has power or authority, i. e., an agency which subordinates all, or at least the overwhelming majority, and ensures the unity of co-existence; that in society there are some general rules imposing obligations on its participants, etc. (Frank, 1992, p. 32). Every society is obliged to use force for the suppression of certain overt actions, and the time between expedient and inexpedient compulsion, will be drawn differently by different persons (Ritchie, 1891, p. 138).

Thus, as we see, the degree of legitimate predominance of group rights over individual ones is a very subjective indicator, which is set in literature. How to find the optimal ratio between growing, according to some researchers, social solidarity and the human right to individuality? It is obvious that there is no moment to talk about some universal formula in this realm.

Society is apt to make mistakes, to number the patriot or the saint among transgressors. But the individual is apt to make mistakes also, and there have been martyrs for bad causes. The limits of justifiable compromise cannot be laid down in any hard and fast apriori rules (Ritchie, 1891, p. 140-141).

In an ideal scenario, a civilized state shall have a developed and social mechanism of settling "disputes" between personal and group rights that should assist in establishing "the favorite right", individual or group, in each particular case. However, there is a critical factor that can largely upset the balance which must exist not only between 
social solidarity and individual freedom but also between group rights and the human right to individuality. The following ideas should be taken into account.

There is in the world at large an increasing inclination to stretch unduly the powers of society over the individual, both by the force of opinion and even by that of legislation; and this encroachment is not one of the evils which tend spontaneously to disappear, but, on the contrary, to grow more and more formidable (Mill, 2001, p. 17). Society has now fairly got the better of individuality; and the danger which threatens human nature is not the excess, but the deficiency, of personal impulses and preferences (Mill, 2001, p. 57). The highest goal of empirical state-public life is the good and the interests of society as a whole, its self-preservation and strengthening, and the conduct of its members should be dedicated to its achievement; society acts and is experienced as a kind of "earthly God" (Frank, 1992, p. 110).

The following should be kept in mind.

Whatever crushes individuality is despotism, by whatever name it may be called, and whether it professes to be enforcing the will of God or the injunctions of men (Mill, 2001, p. 59). Reflecting persons perceived that when society is itself the tyrant - society collectively over the separate individuals who compose it - its means of tyrannising are not restricted to the acts which it may do by the hands of its political functionaries (Mill, 2001, p. 9). Aristotle knew that it is more difficult to be free than not to be free. That political freedom does not exhaust the meaning of freedom ought also to be obvious. Tocqueville noted something related to The Tyranny of the Majority: that a man may be free to express his personal opinions but that against the massive power of "public opinion" (let alone popular sentiment) he was helpless, condemned to a kind of loneliness that was worse than solitude (Lukacs, 2005, p. 130). Tocqueville taught that upon democracy, a public opinion mercilessly stifles every contradictive view and that it takes much more courage to resist the "voice of the people", vox populi, than the order of the autocrat (Jellinek, 1906, p. 46).

Protection, therefore, against the tyranny of the magistrate is not enough. There is a limit to the legitimate interference of collective opinion with individual independence: and to find that limit, and maintain it against encroachment, is as indispensable to a good condition of human affairs, as protection against political despotism (Mill, 2001, p. 9).

Consequently, in our opinion, the maintenance of a good condition of human affairs and hence the harmony of a civilized co-existencein the modern age primarilyinvolves protecting human individuality from mental and emotional captivity and thus establishing and protecting the scope of individual consciousness independent of the control of the majority, even in the form of a public opinion. It is the way - not serving the interests of the majority at any cost - that results in finding the best compromise between growing social solidarity and the human right to individuality.

It is worth drawing attention to some particularities of modern civilization which may under certain circumstances cause the crisis of human individuality under certain circumstances. This entails threats which are driven by faulty, exaggerated understanding and application of the grand conception of human solidarity. In order to clarify the above, the authors resort to the relevant ideas found in the literature.

When scientists and politicians are asked about power limits, the majority answer as follows: minority rights are equal in scope to individual rights. The existence of legally recognized rights of an individual acts as an insurmountable obstacle to the will of the majority. An individual and thus the minority shall possess the right of protest against all attempts of the majority to invade an area that is out of its jurisdiction (Jellinek, 1906, p. 27). Minority rights will be even more crucial to the distant future than to modern lifemoreover, in relation to all areas of public life. Modern society is embraced by an increasingly evolving process of democratization. One can happily welcome this progress, one can be afraid of it, but no force in the world is able to retard this spontaneous historical process for a long time (Jellinek, 1906, p. 44). Personal freedom leads to the equality of individuals, and the striving for it has already become universal (Ramovich, 1903, p. 325). In one place, it is faster, in another - slower; cultural nations are marching towards universal leveling (Jellinek, 1906, p. 44). Equality entails conditions requiring cooperation and solidarity (Ramovich, 1903, p. 325). In an increasingly interdependent global community, any human rights orientation that does not support the widest possible shaping and sharing of values or capabilities among all human beings is likely to provoke widespread skepticism (Weston, 2021).

The division of mankind threatens it with destruction (Sakharov, 1968). In a world increasingly knit together by trade and communications technology, it seems ever more unlikely that the single nation-state can 
on its own successfully handle the universal enemies of poverty, hunger, disease, natural disaster, and war or other violence (Brogan, 2021). International unity is not a luxury, not a dream of idealists, but a life-and-death issue (Fedotov, 2004, p. 173). Having lost the form of a baseless dream or abstract conclusion, solidarity will undoubtedly prove to be an urgent need for humanity (Ramovich, 1903, p. 325)

The more the democratization of society progresses, the more the rule of the majority principle spreads. The more the idea of universal human solidarity suppresses the individual, the less boundaries are recognized by the will of the ruling majority in relation to theindividual. It masks is a terrible danger for the entire civilization (Jellinek, 1906, p. 45). "Civilization" and "culture" are coming to be antithetical terms. Some of the most disinterested solicitude for civilization is apt to be, consciously or unconsciously, inimical to culture (Leavis, 1948, p. 164).

Whatever role coercion, external pressure plays in public life, after all, a participant in the public is a person, a spontaneously acting individual will. It is the only engine of public life, and everything else in society is a transmission mechanism in relation to it (Frank, 1992, p. 115). One can feel like an integral part and, at the same time, the bearer of the only specific individual whole - a specific family, the specific people, a specific church. The true "we" is as individual as "I" and "you". In this context, humanitarianism replaces a living feeling and a specific intrinsic relation with a powerless abstract principle (Frank, 1992, pp. 61-62).

The most urgent social need involves providing a person with such a scope that would be free from the influence of the state and society and within which the person would not be obliged to obey any majority. Nothing can be more merciless and relentless, nothing can be more hostile to the most elementary rights of the individual, nothing can so hate and despise everything great and genuine as a democratic majority (Jellinek, 1906, p. 45, 47).

J. Ortega y Gasset, in "The Revolt of the Masses", invented the phrase of "modern Mass Man". J. Ortega y Gasset wrote about the masses made up by men whose opinions and ideas, whose physical and, more important, mental behavior may be unoriginal, middling, crude. A majority, like an aristocratic minority, or like a monarch, may be right or wrong; and when it is wrong, to change it or its consequences may be long, arduous, for a while seeming hopeless (Lukacs, 2005, p. 175-176).
Thus, in the authors' opinion, the above review allows making definitive conclusions that "the interest of the majority" per se without its civilized "fertilization" with the idea of an absolute value of human personality is at least not identical, rather opposite to the "harmony of civilized life". One can hold that an unjustified "invasion" of the public will in the realm of individual freedom and the actual suppression of the human right to individuality, which become possible due to the lack of effective legal and social safeguards against the public will, are often the consequences of the collision between individual and group rights in modern societies. It is also essential to pose questions on objectively available obstacles to the implementation of such an important and integral part of the human right to individuality as the aspiration to have and support one's cultural identity as well on hindering the development of the very aspiration which originates from modern civilization. Does it deplete modern threats to the right to individuality?

\section{The significance of intellectual liberties} in mass societies

More important is the question how much (if any) of intellectual liberties matter in mass societies (Lukacs, 2005, p. 130).

In order to study the relevant issue and determine the place and significance of intellectual freedom of man, which we consider as one of the dimensions of his freedom, the structure of the right to individuality requires studying existing scientific and philosophical approaches to theoretical analysis of the phenomenon under consideration and challenges to its existence in the modern world.

Intellectual freedom is essential to human society - freedom to obtain and distribute information, freedom for open-minded and unfearing debate and freedom from pressure by officialdom and prejudices (Sakharov, 1968). Widely shared experiences and freedoms of the public always need updating and renewing with freshness and new ideas (Guyau, 1900, p. 433). Everything new actually begins with nothing in that mysterious deepest center of the personality, which we call freedom. After being conceived and gradually shaping in the depths of the individual spirit, in the creative personal initiative, the new is subsequently perceived by the social environment, penetrates it, and becomes consolidated in it (Frank, 1992, p. 126).

But freedom of thought is under a threat in modern society (Sakharov, 1968). In "Was ist Aufklärung?” I. Kant drew a vital distinction between the public and private use of one's 
reason (Treasure, 2021). In 1784 I. Kant wrote: "A high degree of civil freedom seems advantageous to a people's intellectual freedom, yet also sets up insuperable barriers to it. Conversely, a lesser degree of civil freedom gives intellectual freedom enough room to expand to its fullest extent" (as cited in (Treasure, 2021)). Stendhal argued that "the factors which are essential if art is to flourish are often diametrically opposed to those which are indispensable if a nation is to be happy. $<$... $>$ Should we not $<_{\text {... }}>$ suppose this dispiriting cheerlessness $<\ldots>$ to be the necessary price and consequence of liberty?" (Stendhal, 1959, p. 400, 445).

To clarify the above, the authors consider the following statements.

At all times of each new great thought, each idea, which subsequently shook the whole world, had to make its way, not without difficulty and danger, contrary to the resistance of the ruling forces. Democratic society resists a hundred times stronger than any other (Jellinek, 1906, p. 46).

Let us consider one of the examples that most vividly illustrates the situation in which a person's individuality in the realm of intellectual freedom may concede to social solidarity; moreover, a person may be directly required to sacrifice his individuality in favor of group rights. Let's speculate whether such an approach can be justified by any supreme goal.

It seems that the despotism of vox populi never influences the person so imperatively as in terms of the formation of aesthetic judgments. Our enthusiasm is landed in us without our knowledge (Tarde, 1895, p. 43). At any given moment in society, there must be a lot of such judgments ready to become concepts and then aesthetic feelings, often erroneous prejudices which the artist - creator - must always consider; if he attempts to attack these beliefs bluntly, risking to be foundered on them - or even if he does not bother to agree them with new judgments of taste that he intends to make admitted - then he finds himself disregarding (neglecting) his social mission of enrichment not reduction, strengthening not weakening the links of social faith, which is the common goal of logic, both social and aesthetic, and a feature of their relationship (Tarde, 1895, p. 44).

However, does not the declared social mission come at a price? Does the person, who seeks to protect a particular scope of individual consciousness from one that he regards as encroachment, have the right not to succumb to social pressure, even in the form of public opinion? Can resistance to the will of the majority in the specific realm be considered anti-social behavior? What features of modern intellectual life cause a natural decrease in the intellectual freedom of man, which is discussed by some researchers? The questions need to be covered in detail.

Actually, each individual is aware of himself as the absolute beginning; "I" is the very point where an absolute being reaches selfconsciousness; it perceives the whole empirical world, including society, as an environment and means for self-fulfillment and therefore can never come to terms with its position as a means or a body of public good. Consciousness is not identical with gross egoism (Frank, 1992, p. 110).

If culture should be understood as a conscious attitude to oneself and the world - it seems that culture cannot be defined differently - it is obvious that increasing hypertrophy of the conscious beginning within each individual inevitably accompanies cultural progress (Gershenzon, 1915, p. 51). If there is a firmly established course for the development of culture, then this is the course of an ever-greater mind expansion, a line of mental growth, ever-greater destruction of stupidity (Müller-Lyer, 1925, p. 257).

As M. Kundera put it, "in the modern world of technology and mass media, the prospects for culture were not bright" (Kundera, 1984, p. 36). Modern technology and mass psychology constantly suggest new possibilities of managing the norms of behavior, the strivings and convictions of masses of people. Civilization is imperiled by stupefaction from the narcotic of "mass culture" (Sakharov, 1968).

Here Tocqueville is again pertinent. He believed, and wrote, that ideas, indeed intellectual life, in the democratic age move, and will move, very slowly. His contemporaries believed that with the rise of democracy ideas would gather speed, sometimes dangerously so: that the awakened populations would force the political and social to swing to extremes, perhaps from one extreme to the other. Tocqueville recognized the very opposite. He wrote not only that the monstrous accumulating weight of public opinion might lead to (or even constitute) a tyranny of the majority, but that it actually slows down the movement of ideas, dependent as those are on their acceptability by large masses of people. He foresaw the considerable and often dangerous condition of democratic stagnation, in intellectual as well as in political life (Lukacs, 2005, pp. 178-179).

In our opinion, both above standpoints about intellectual life in the democratic epoch are accurate and do not exclude each other. The below statements justify our approach. 
In the part where the principle of preserving the old is so comprehensive and intense that it begins to absorb and suppress the freedom of personal initiative and creative construction, the very fundamental principle of society spiritual life - begins to fade away: since life per se is a relentless flow of becoming, a creative impulse, an influx of new forces and contents into the human experience of being continuously generated in the depths of a free spirit. When the influx is delayed and weakens or stops, the protection itself loses its meaning because there is no real material for it; the commencement of protection, the continuity of living being turns into the ossification of empty forms. However, everything ossified, paralyzed, deprived of an influx of living spiritual blood inevitably falls apart; on the other hand, the delayed flow of spiritual creativity, without finding its direct embodiment, becomes a destructive whirlpool of rebellion, a force internally poisoned by its painful distortion, transforming it from a creative element into a destructive element. Protection similarly becomes destruction (Frank, 1992, pp. 126-127). today

We hold the following words are relevant

Nowadays, virtually all countries of the Western world are characterized by a dangerous tendency to erode the foundations of the political center, when the extreme rightwingersattack the principles ofliberaldemocracy, and extreme left-wingers - the principles of the market economy (Kasparov, 2020). In many countries, nationalism, nativism, and xenophobia still distort voters' judgments in matters of foreign policy, as greed misleads them over economic policy. Class conflicts have been muted rather than resolved. Demagogues abound as much as they did in ancient Athens (Brogan, 2021). Now there is such ideological and mental chaos that people have quit recognizing threats. They do not understand what poses a threat. It is a common feature to the whole democratic world. (Pomorski, 2019). The economic system of the Western world has become less flexible, less efficient, less dynamic, and less innovative than it was. Thus, against the backdrop of these processes, it is appeared generations which have poor knowledge of history (historical knowledge is undervalued) and find demagogic slogans very attractive (Kasparov, 2020). The common absence of concern for what is happening is not to be explained by erudition or philosophy. It is itself a symptom (Leavis, 1948, p. 145). Democracy is becoming more elite, the matter of a limited number of people, while the Internet, social networks give something that was called direct democracy when every populist can, through mechanisms and algorithms, address literally every person and promise him what he wants or what he has imagined. Does this mean that the role of intellectuals, who have somehow affected society in old communication relations, is now disappearing due to new communication links, the Internet, and social networks? (Pomorski, 2019). According to psychologists, the World Wide Web is deprived of the essence of intellectuality, "I understand" in Latin. Awareness, even as an "intelligent product", will not transform a consumer of the all-encompassing Internet into an intelligent person (Drahan, 2000). As F.R. Leavis put it earlier "the modern is exposed to a concourse of signals so bewildering in their variety and number that, unless he is especially gifted or especially favoured, he can hardly begin to discriminate" (Leavis, 1948, p. 158). In fact, there is a danger that "net culture", after becoming public through eliminating differences, will become a nightmare of civilization (Drahan, 2000).

In this context, the question arises: what should be contrasted with the considered crisis phenomena, which characterize the intellectual life in the epoch of modern democracy and technologies? To answer the question, it is primarily essential to find out the guide which a modern person should have to properly assess the current state of affairs in the realm of intellectual freedom.

Even an imperfect system is better than a lack of any system. The truth may be revealed based on developments, even if erroneous rather than based on a real mess (MüllerLyer, 1925, p. 43). We have no thread through the enormous intricacy and complexity of modern politics except the idea of progress towards more perfect and assured freedom (Dalberg-Acton, 1921, p. 202).

As one author put it "we should focus $<\ldots>$ on how we can learn to be selective in what we see and learn how social media truly works" (Grant, 2021). No one in the world has yet invented vaccination against algorithms on social networks (Pomorski, 2019).

However, we believe that a way out exists.

There are sudden abrupt transitions from complete immobility and inertia to spontaneous rebellion. There is only one salvation from this evil - the development of a conscious individual (Trubetskoy, 1918, p. 43). Furthermore, we must not forget that discussion itself is one of the most important means of education (Ritchie, 1891, pp. 138-139). The right of spreading one's opinions implies certain legal and constitutional securities and a certain condition of public sentiment. Without explicitly recognized legal safeguards 
public sentiment is a somewhat fickle protector of liberty. Outbursts of fear, fanaticism, and intolerance are only too possible (Ritchie, 1891, p. 137)

Thus, it is imperative to statutorily consolidate the right to intellectual right as an integrated part of the human right to individuality. The authors propose formulating the statutory definition of the right of a natural person to intellectual freedom: "A natural person has the right to intellectual freedom - the right to the development of a conscious attitude to oneself and the world, the implementation of personal creative initiative, mental growth, incl. through discussions. A natural person is free to judgments, concepts, feelings, and prejudices of surrounding opinion until it does not harm others".

\section{Conclusions}

The authors hold that the following measures may assist in addressing the issues associated with the growing social solidarity with the human right to individuality:

- it is proposed to highlight that studying theoretical approaches to the analysis of the history of the human right to individuality and individual freedom available in scientific and philosophical thoughts can contribute to a better understanding of individual freedom and its significance in the modern world;

- it is proposed to state that despite the eventually declared triumph of individualism as a defining feature of our time, the issue of a proper understanding of personal freedom is still relevant. As the history of mankind shows, a misunderstanding of the phenomenon by masses threatens civilization with serious social diseases and catastrophes;

- it is proposed to support the standpoint found in the literature under which personal human freedom is primarily important as a fundamental means for the achievement of other goals, among which the advancement of human individuality is a priority;

- it is proposed to admit the very advantage of individualism over the glorification of the state is insufficient that human individuality can make continuous progress;

- it is proposed to declare that "the interest of the majority" per se without its civilized "fertilization" with the idea of an absolute value of human personality is at least not identical, rather opposite to the "harmony of civilized life";
- it is proposed to understand that an unjustified "invasion" of the public will in the realm of individual freedom and the actual suppression of the human right to individuality, which become possible due to the lack of effective legal and social safeguards against the public will, are often the consequences of the collision between individual and group rights in modern societies;

- it is proposed to declare that faulty, hypertrophied understanding and application of the grand conception of human solidarity may cause the crisis of human individuality in modern civilization; the crisis may be manifested, inter alia, in obstacles to the aspiration to have and support one's cultural identity and in hindering the very development of that sort of the aspiration;

- it is proposed to recognize that intellectual freedoms and intellectual life in modern mass societies are becoming relevant and, at the same time, are under specific threat;

- it is proposed to add para. 3 to art. 300 of the Civil Code of Ukraine and present it in the version as follows: "A natural person shall have the right to intellectual freedom - the right to the advancement of conscious attitude to oneself and the world, the implementation of personal creative initiative, intellectual development, incl. through discussion. A natural person shall be free from judgments, concepts, feelings, and prejudices of others' opinion, as long as it does not harm others". The authors hold that human individuality is incomplete in the modern world without promoting intellectual freedom.

The authors believe that further study of the human right to individuality is essential to respond to a range of challenges, namely: harmonization of interests of the individual and the state in terms of the circulation and processing of personal information; identification of the ratio between the tangible form of the intangible good and intangible good as it is; finding the optimal correlation between intellectual property rights and the interests of society in the free use of information that is the object of intellectual property right; striking a balance between the right to privacy and the right to seek, receive, impart and disseminate information.

\section{References:}

Barth, P. (1902). Filosofiya istorii kak sotsiologiya [The Philosophy of History as Sociology], transl. by M.S. Model. Saint Petersburg: S.-Peterburgskaya elektropechatnya [in Russian].

Barzun, J. (2021). Modern culture. History of Europe. Retrieved from: https:// www.britannica.com/topic/history-of-Europe/Modern-culture [in English].

Brogan, H. (2021). Government. Retrieved from: https://www.britannica.com/topic/ government [in English]. 
Creighton, M. (1949). Letter to Lord Acton (April 9, 1887). Essays on Freedom and Power / ed. by G. Himmelfarb. Boston: The Beacon Press, Mass., pp. 370-373. Retrieved from: https:// cdn.mises.org/Essays\%20on\%20Freedom\%20and\%20Power_3.pdf [in English].

Dahl, R.A. (2021). Democracy. Retrieved from: https://www.britannica.com/topic/democracy [in English].

Dalberg-Acton, J.E.E. (1921). Lectures on Modern History / ed. by J.N. Figgis, R.V. Laurence. London: Macmillan and co., St. Martin's Street. Retrieved from: https://cdn.mises.org/Lectures\%20 on\%20Modern\%20History_3.pdf [in English].

Dalberg-Acton, J.E.E. (1949). Essays on Freedom and Power / ed. by G. Himmelfarb. Boston: The Beacon Press, Mass. Retrieved from: https://cdn.mises.org/Essays\%20on\%20Freedom\%20 and\%20Power_3.pdf [in English].

Drahan, O. (2000). Net-kultura - strashnyi son tsyvilizatsii [Net Culture - the Nightmare of Civilization]. Shchodenna vseukrainska hazeta "Den" - Daily All Ukrainian Newspaper "Day", vol. 76. Retrieved from: https://day.kyiv.ua/uk/article/kultura/net-kultura-strashniy-soncivilizaciyi [in Ukrainian].

Dzera, O.V., Kuznietsova, N.S., Luts, V.V. (eds.) (2019). Naukovo-praktychnyi komentar Tsyvilnoho kodeksu Ukrainy [Scientific and Practical Commentary of the Civil Code of Ukraine], in 2 vols. Kyiv: Yurinkom Inter [in Ukrainian].

Fedotov, G.P. (2004). Sobraniye sochineny [Collected works], in 12 vols. Vol. 9: Statyi amerikanskogo perioda [Articles of American period]. Moscow: Martis. Retrieved from: https:// imwerden.de/pdf/fedotov tom09 amerikansky period 2004.pdf [in Russian].

Frank, S.L. (1992). Dukhov̄nyye osnovy obshchestva: voedeniye v sotsialnuyu filosofiyu [The spiritual foundations of society: an introduction to social philosophy] / ed. by P.V. Alekseyev. Moscow: Respublika [in Russian].

Gershenzon, M.O. (1915). Franchesko Petrarka. Vstupitelny ocherk [Francesco Petrarca. An introductory essay]. Petrarca F. Avtobiografiia. Ispoved. Sonety [Autobiography. Confession. Sonnets] / transl. by M.O. Gershenzon, V.I. Ivanov. Moscow: Izdaniye M. i S. Sabashnikovykh, pp. 3-52 [in Russian].

Grant, K. (2021). Influencers react to Norway photo edit law: "Welcome honesty" or a "shortcut"? Nerosbeat reporter, July 6. Retrieved from: https://www.bbc.com/news/newsbeat-57721080 [in English].

Guyau, J.-M. (1900). Iskusstvo s sotsiologicheskoi tochki zreniia [Art from the Sociological Point of View] / ed. by G. Falbork, V. Charnoluskiy. Saint Petersburg: Tipografiya Tovarishchestva "Narodnaia polza" [in Russian].

Jellinek, G. (1906). Prava menshinstva [The Rights of Minority] / ed. by M.O. Gershenzon. Moscow: Izdaniye M. i S. Sabashnikovykh [in Russian].

Kasparov, G. (2020). Borba za initsiativu [Fight for the initiative]. Kasparoz.Ru: internetgazeta svobodnoy Rossii - Kasparov.Ru: online newspaper of free Russia, January 6. Retrieved from: https://www.kasparov.ru/material.php?id=5E125A59AFA8B [in Russian].

Kharytonov, Ye.O., Kharytonova, O.I. (eds.) (2018). Aktualni problemy tsyvilistyky u tsy frovu dobu [Topical issues of civil law in the digital era]. Odesa: Yurydychna literatura [in Ukrainian].

Kodynets, A.O. (2016). Tsyvilno-pravove rehuliuvannia zoboviazalnykh informatsiinykh vidnosyn [Civil lawe regulation of obligatory information relations]. Kyiv: Alerta [in Ukrainian].

Kokhanovska, O.V. (2006). Teoretychni problemy informatsiinykh vidnosyn u tsyvilnomu pravi [Theorethical problems of informational relations in the civil law]. Kyiv: Vydavnycho-polihrafichnyi tsentr "Kyivskyi universytet" [in Ukrainian].

Kokhanovska, O.V. (2020). Osoblyvosti onovlennia tsyvilnoho zakonodavstva Ukrainy u sferi prava na informatsiiu $\mathrm{v}$ umovakh rozvytku hlobalnoho virtualnoho seredovyshcha [Features of updating the civil legislation of Ukraine in the field of the right to information in the conditions of development of the global virtual environment]. Visnyk Natsionalnoi akademii pravovykh nauk Ukrainy - Journal of the National Academy of Legal Sciences of Ukraine, vol. 27, no. 4, pp. 145-160. DOI: 10.37635/jnalsu.27(4).2020.145-160 [in Ukrainian].

Kulinich, O.O. (2016). Pravo fizychnoi osoby na vlasne zobrazhennia: suchasnyi stan ta perspektyoy rozvytku [The right of private person to the own image: current status and prospects of development]. Odesa: Yurydychna literatura [in Ukrainian].

Kundera, M. (1984). The Tragedy of Central Europe / transl. by E. White. The New York Review of Books, no. 7(31), pp. 33-38. Retrieved from: https://is.muni.cz/el/1423/jaro2016/MEB404/ um/Kundera_1984.pdf [in English].

Kushakova-Kostytska, N.V. (2018). Pravo na informatsiiu v informatsiinu epokhu (porivnialne doslidznennia) [The right to information in the information age (comparative investigation)] / ed. by M.V. Kostytsky. Kyiv: Logos [in Ukrainian]. 
Kuznietsova, N.S., Kharytonov, Ye.O., Maidanyk, R.A. et al. (eds.) (2013). Pravova doktryna Ukrainy: doktryna pryvatnoho prava Ukrainy [The legal doctrine of Ukraine: the doctrine of private law of Ukraine], in 5 vols. Kharkiv: Pravo [in Ukrainian].

Leavis, F.R. (ed.) (1948). Mass Civilization and Minority Culture. Education and the University: A Sketch for an "English School". London: Chatto \& Windus; Toronto: Oxford University Press, pp. 141-171. Retrieved from: https://ia801600.us.archive.org/34/items/in.ernet. dli.2015.503100/2015.503100.education-and_text.pdf [in English].

Lukacs, J. (2005). Democracy and Populism: Fear and Hatred. New Haven: Yale University Press. Retrieved from: https://dokumen.pub/democracy-and-populism-fear-andhatred-0300107730-9780300107739.html [in English].

Mill, J.S. (2001). On Liberty. Kitchener: Batoche Books. Retrieved from: https:// socialsciences.mcmaster.ca/econ/ugcm/31l3/mill/liberty.pdf [in English].

Montgomery, B.L. (1968). A History of Warfare / ed. by J. Hadfield, G. Speaight. Cleveland; New York: The World Publishing Company. Retrieved from: https://www.worldhistory.biz/ download567/AHistoryofWarfare_worldhistory.biz.pdf [in English].

Müller-Lyer, F. (1925). Sotsiōogiya stradaniy [Sociology of Sufferings] / ed. by P. Berman. Moscow; Leningrad: Zemlya i fabrika [in Russian].

Petryshyn, O.V., Hyliaka, O.S. (2021). Prava liudyny v tsyfrovu epokhu: vyklyky, zahrozy ta perspektyvy [Human rights in the digital age: challenges, threats and prospects]. Visnyk Natsionalnoi akademii pravovykh nauk Ukrainy - Journal of the National Academy of Legal Sciences of Ukraine, vol. 28, no. 1, pp. 15-23. DOI: 10.37635/jnalsu.28(1).2021.15-23 [in English].

Pomorski, A. (2019). Polskyi stratehichyi punkt - tse stabilna Ukraina [Poland's strategic point is a stable Ukraine]. Espreso - ukrainskyi pohliad na svit - Espresso is the Ukrainian view of the world, June 9. Retrieved from: https://espreso.tv/article/2019/06/08/adam_pomorskyy [in Ukrainian].

Posykaliuk, O.O. (2012). Osobysti nemainovi prava fizychnykh osib v romanskii, hermanskii, anhlo-amerykanskii systemakh pryvatnoho prava [Personal intangible rights of individuals in Romanic, Germanic, Anglo-American systems of private law]. Kyiv: Naukovo-doslidnyi instytut pryvatnoho prava i pidpryiemnytstva Natsionalnoi akademii pravovykh nauk Ukrainy [in Ukrainian].

Ramovich, E. (1903). Individualnost $i$ progress: etudy [Individuality and Progress: etudes]. Saint Petersburg: Tipografiya N.N. Klobukova [in Russian].

Ritchie, D.G. (1891). The Rights of Minorities. International Journal of Ethics, vol. 1, no. 2, pp. 129-142. Retrieved from: https://www.journals.uchicago.edu/doi/pdf/10.1086/ intejethi.1.2.2375404 [in English].

Robinson, C., Birkett, J. (2021). From 1850 to 1900. French literature. Retrieved from: https://www.britannica.com/art/French-literature/From-1850-to-1900 [in English].

Sakharov, A.D. (1968). Thoughts on Progress, Peaceful Coexistence and Intellectual Freedom. The New York Times, July 22. Retrieved from: https://www.sakharovcenter-vdu.eu/assets/files/ sakharov-thoughts-in-nyt.pdf [in English].

Slipchenko, S.O. (2013). Osobysti nemainovi pravovidnosyny shchodo oborotozdatnykh obiektiv [Personal non-property relations concerning negotiable objects]. Kharkiv: Disa plius [in Ukrainian].

Spasybo-Fatieieva, I.V. (ed.). (2021). Tsyvilnyi kodeks Ukrainy: naukovo-praktychnyi komentar [Civil Code of Ukraine: scientific and practical commentary], in 2 vols. Kharkiv: EKUS [in Ukrainian].

Stefanchuk, R.O. (2007). Osobysti nemainovi prava fizychnykh osib u tsyvilnomu pravi (poniattia, zmist, systema, osoblyvosti zdiisnennia ta zakhystu) [Personal intangible rights of individuals in the civil law (concept, content, system, special aspects of conduct and protection]. Khmelnytskyi: Vydavnytstvo Khmelnytskoho universytetu upravlinnia ta prava [in Ukrainian].

Stefanchuk, R.O. (ed.). (2010). Lichnyye neimushchestvennyye prava: problemy teorii i praktiki primeneniya [Personal intangible rights: problems of theory and practice of application]. Kyiv: Yurinkom Inter [in Russian].

Stendhal (1916). The Red and the Black / transl. by H.B. Samuel. London: Kegan Paul, Trench, Trübner \& Co., Ltd; New York: E.P. Dutton and Co. Retrieved from: https://ia902607.us.archive. org/20/items/redblackchronicl00steniala/redblackchronicl00steniala.pdf [in English].

Stendhal (1959). Rome, Naples and Florence / transl. by R.N. Coe. London: John Calder (Publishers) Ltd. Retrieved from: https://ia803000.us.archive.org/9/items/Rome NaplesAndFlorenceStendhal17831842/Rome\%2C\%20Naples\%2C\%20and\%20Florence\%20-\%20 Stendhal\%2C\%201783-1842.pdf [in English].

Tarde, G. (1895). Sushchnost iskusstva [The essence of art] / ed. by L.Ye. Obolenskiy. Saint Petersburg: Izdaniye V.I. Gubinskogo [in Russian].

Treasure, G.R.R. (2021). The great age of monarchy, 1648-1789. History of Europe. Retrieved from: https://www.britannica.com/topic/history-of-Europe/The-great-age-of-monarchy-1648-1789 [in English]. 
Trubetskoy, E.N. (1918). Dva Zverya. Staroye i novoye [The Two Beasts. The Old and the New]. Moscow: Tipografiya Tovarishchestva I.D. Sytina. Retrieved from: https://viewer.rusneb.ru/ru/ rsl01002577764?page $=1 \&$ rotate $=0 \&$ theme $=$ white [in Russian].

Trubetskoy, E.N. (1919). Zverinoye tsarstvo i gryadushcheye vozrozhdeniye Rossii [The kingdom of the beast and the coming renaissance of Russia]. Retrieved from: https://viewer.rusneb.ru/ru/ rsl01004416732? page $=1 \&$ rotate $=0 \&$ theme $=$ white [in Russian].

Weston, B.H. (2021). Human rights. Retrieved from: https://www.britannica.com/topic/ human-rights [in English].

Zaika, Yu. (2017). Zakhyst chesti ta hidnosti za zakonodavstvom krain kontynentalnoi Yevropy [Protection of honor and dignity in terms of the continental European states law]. Istoryko-pravovyi chasopys Skhidnoievropeiskoho universytetu imeni Lesi Ukrainky - Historical and Legal Journal of Lesya Ukrainka Eastern European University, no. 2(10), pp. 70-75. Retrieved from: https://evnuir. vnu.edu.ua/bitstream/123456789/13903/1/14\%20zaika.pdf [in Ukrainian].

Zaika, Yu.O., Kukhariev, O.Ye., Skrypnyk, V.L., Mytnyk, A.A. (2021). Peculiarities of Protection of Rights and Interests of Heirs: Theoretical Aspects. International Journal of Criminology and Sociology, vol. 10, pp. 355-362. Retrieved from: https://doi.org/10.6000/1929-4409.2021.10.43 [in English].

\section{Tapac Софіюк,}

кандидат юридичних наук, доцент кафедри міжнародного, иивільного та комериійного права, Київський начіональний торговельно-економічний університет, вулиия Кіото, 19, Київ, Україна, індекс 02156, t.sofiuk@gmail.com

ORCID: orcid.org/0000-0002-8949-3336

Scopus Author ID: 57217833407

\section{Лариса Нескороджена,}

кандидат юридичних наук, дочент кафедри міжнародного, иивільного та комериійного права, Київський національний торговельно-економічний університет, вулиия Кіото, 19, Київ, Україна, індекс 02156, l.neskorodzhena@knute.edu.ua

ORCID: orcid.org/0000-0002-1484-3557

\section{Юлія Кабенок,}

кандидат юридичних наук, дощент кафедри міжнародного, цивільного та комерційного права, Київський національний торговельно-економічний університет, вулиия Кіото, 19, Киї, Україна, індекс 02156,y.kabenok@knute.edu.ua

ORCID: orcid.org/0000-0001-9342-3835

Scopus Author ID: 57212105878

\section{ПРАВО ФІЗИЧНОЇ ОСОБИ НА ІНДИВІДУАЛЬНІСТЬ}

Анотація. Метою роботи є обгрунтування необхідності законодавчого закріплення права людини на інтелектуальну свободу як невід'ємної складової частини права фізичної особи на індивідуальність.

Методи дослідження. Роботу виконано на підставі таких методів наукового пізнання, як науковий аналіз, синтез, вивчення інформаційних джерел, логіко-семантичний, формально-логічний, діалектичний, ретроспективний, прогностичний методи.

Результати. У роботі вивчено теоретичні підходи до аналізу історії права людини на індивідуальність та індивідуальну свободу, наявні в науковій і філософській думці. Приділено увагу розумінню поняття індивідуальної свободи та її значення в сучасному світі. Дослідження показало, що підтримання суспільного добробуту ( good condition of human affairs), а отже, і гармонії цивілізованого побуту, нині полягає насамперед у захисті людської індивідуальності від розумової та емоційної несвободи, а також у встановленні й охороні обсягу індивідуальної свідомості, що не підвладний волі більшості, навіть у формі громадської думки. Доведено, що «інтерес більшості», узятий сам по собі, без цивілізуючого «запліднення» його ідеєю безумовної цінності людської особистості, щонайменше не тотожний, якщо не протилежний «гармонії цивілізованого побуту». Показано, що наслідками зіткнення індивідуальних і групових прав у сучасних суспільствах часто стають невиправдане «вторгнення» волі більшості в царину індивідуальної свободи та фактичне придушення права людини на індивідуальність, які стають можливими через відсутність дієвих правових і суспільних запобіжників на шляху волі мас. Вивчено питання значущості інтелектуальної свободи в масових суспільствах. З'ясовано особливості інтелектуального життя в демократичну епоху. 
Приділено увагу загрозам свободі думки, які існують у сучасну епоху. Вказано на необхідність розвитку та захисту інтелектуальної свободи людини.

Висновки. За результатами проведеного дослідження обгрунтовано такі висновки щодо гармонізації індивідуальності людини із суспільною солідарністю: 1) пропонується визнати, що неправильне, гіпертрофоване розуміння й застосування шляхетної ідеї людської солідарності може призводити до кризи індивідуальності людини в сучасній цивілізації; 2) ця криза може проявлятися, зокрема, у виникненні перешкод для реалізації прагнення мати та підтримувати свою культурну самобутність, а також у стримуванні самого розвитку цього прагнення; 3) пропонується визнати, що інтелектуальні свободи та інтелектуальне життя в сучасних масових суспільствах набувають особливої ваги й водночас перебувають під особливою загрозою; 4) до ст. 300 Цивільного кодексу України пропонується додати нову ч. 3, яку необхідно викласти в такій редакції: «Фізична особа має право на інтелектуальну свободу - право на розвиток свідомого ставлення до себе та до світу, на реалізацію творчої особистої ініціативи, на розумове зростання, зокрема й шляхом дискусії. Фізична особа $є$ вільною від суджень, понять, почуттів та упереджень оточення, доки вона не заподіює шкоду іншим». Ми вважаємо, що без особливого сприяння інтелектуальній свободі в сучасному світі індивідуальність людини є неповною.

Ключові слова: індивідуальність, індивідуальна свобода, громадська думка, «тиранія більшості», культура, масове суспільство, інтелектуальна свобода.

The article was submitted 08.11.2021

The article was revised 29.11.2021

The article was accepted 20.12.2021 